\title{
Klisura/Rozino granite, Central Sredna Gora: a part of the story of late Permian-Early Triassic extensional magmatic event
}

\section{Клисурски/Розински гранит, Централна Средна гора: част от историята на къснопермско-раннотриаско екстензионно магматично събитие}

\author{
Anna Lazarova', Igor Broska ${ }^{2}$,Martin Svojtka ${ }^{3}$, Kalin Naydenov ${ }^{1}$ \\ Анна Лазарова ${ }^{1}$, Игор Броска ${ }^{2}$, Мартин Свойтка $^{3}$, Калин Найденов ${ }^{1}$ \\ ${ }^{1}$ Geological Institute, Bulgarian Academy of Sciences, 1113 Sofia, Bulgaria; E-mail: alazarova@geology.bas.bg \\ ${ }^{2}$ Earth Science Institute, Slovak Academy of Sciences, Dúbravská cesta 9, 84005 Bratislava, Slovakia \\ ${ }^{3}$ Institute of Geology of the Czech Academy of Sciences, 269 Rozvojová, 16500 Prague, Czech Republic
}

\begin{abstract}
The late- to post-Variscan magmatic activity in the South Black See region took place during a considerably long period of ca. 80 from Late Carboniferous up to Early-Mid Triassic as two episodes are distinguished. The obtained age of $253.6 \pm 1.6 \mathrm{Ma}$ for the Klisura/Rozino granite gives further evidence of the contemporaneous intrusive and extrusive magmatism during late Permian and Early Triassic in the Sredna Gora and Balkan zones.
\end{abstract}

Keywords: late Permian-Early Triassic magmatism, Central Sredna Gora, Central Balkan, U-Pb zircon geochronology.

\section{Introduction}

The pre-Mesozoic crystalline basement of the Central Balkans comprises huge batches of Lower Carboniferous to Triassic magmatic rocks (e.g. Okay, Topuz, 2017). In Bulgaria, a number of late syn- to post-tectonic igneous and volcanic rocks are hosted within the Variscan low- and high-grade metamorphic units of the basement of Sredna Gora and Balkan zones and Ograzhden Unit of the Serbo-Macedonian Massif, as parts of the Carpatho-Balkanides. In general, during the Alpine orogeny, they were located in the so-called peri-Tethyan region, thus escaping the strong high-grade metamorphic overprint and fabric reworking, unlike the protoliths in the highly deformed Rhodope Massif and SakarStrandzha zone. This allows more straightforward geochemical and geochronological differentiation of diverse pre-Alpine tectonic and magmatic events.

The geochronologic data, obtained in the last twenty years clearly show that the late to postVariscan, but pre-Alpine magmatic activity took place during a considerably long period of ca. 80 Ma from Late Carboniferous up to Early-Mid Triassic. In spite some ideas of a long-lived uninter- rupted magmatic activity on a regional scale for the Western Mediterranean, Southern Europe and Northern Africa, Cortesogno et al. (2004) proposed two magmatic episodes: i) from Late Carboniferous to early Permian with calc-alkaline and low to high$\mathrm{K}$ magmatic products related to the orogenic collapse of the Variscan Belt, and ii) from Permian to Triassic with an intermediate to alkaline affinity of the magmas, associated to extensional tectonics and rifting that preluded the Jurassic oceanization. Antic et al. (2016) specified the time of both episodes of a magmatic activity within the Serbo-Macedonian Massif and the adjacent basement units as Carboniferous (late Variscan; 328-304 Ma) and late Permian to Early Triassic (255-253 Ma). Presently, the Late Carboniferous to early Permian magmatic activity for the Balkan and Sredna Gora zones is well constrained and most of the ages range between ca. 318-285 Ma. In contrast, the products of the second episode are still insufficiently studied and frequently considered under the collective name "Permian magmatic rocks". Here, we are presenting a precise data, giving the crystallization age of the Klisura/ Rozino granite (central part of the Sredna Gora Zone) - an igneous body, for which only prelimi- 
nary geochronological data (Antonov et al., 2010) indicate late Permian (259.8+4.5/-6.4 Ma) emplacement. Additional aim is to put this data in the regional geodynamic context suggested for the Late Carboniferous to Triassic magmatism, thus further supporting the two-episode concept for the Sredna Gora and Balkan zones and Ograzhden unit of the Serbo-Macedonian Massif.

\section{Results}

The Klisura/Rozino granite occupies the northern periphery of Central Sredna Gora in the surroundings of the town of Klisura and northwards in the Vezhen Massif of Central Stara planina Mountain (Fig. 1). The body intruded the Anton and Karavelovo granites, is still undated, but with presumed Late Carboniferous ages. East of the Vezhen summit, the contact of the Klisura/Rozino granite with the Upper Carboniferous Vezhen pluton (314 $\pm 5 \mathrm{Ma}$, Kamenov et al. 2002; 307 $\pm 1 \mathrm{Ma}$, Georgiev et al. 2020), coincides with the Alpine brittle-ductile Bratanitsa shear zone, which obliterated the primary (intrusive) relationships. Most common varieties in the Klisura/Rozino granite are coarse-grained
K-feldspar-phyric (up to $1 \mathrm{~cm}$ ) biotite granites (Kuykin et al., 1974; Antonov et al., 2010) with main rockforming minerals $\mathrm{K}$-feldspar, plagioclase, quartz, biotite, and accessories apatite, zircon and titanite.

The sample KL-1 (N4731026.2; E289442.9) is a coarse-grained K-feldspar-phyric granite with imposed weak cataclasis and hydrothermal alteration, most probably related to the brittle normal faulting along the flanks of the neighboring Neogene-Quaternary Zlatitsa graben. The analytical work was done at the Institute of Geology of the Czech Academy of Sciences, Prague, Czech Republic, using Thermo Scientific Element 2 magnetic sector-field ICP-MS coupled to a $193 \mathrm{~nm}$ ArF excimer laser (Teledyne/Cetac Analyte Excite laser) equipped with a HelEx II active 2-volume ablation cell. During the data reduction, analyses that showed signs of mixing or spiking of microinclusions have been discarded. The zircon grains are rather uniform with prismatic to stubby euhedral shapes or their fragments, 120-300 $\mu \mathrm{m}$ long. They contain a lot of pores and inclusions riddled with multiple fracturing (BSE image; Fig. 1). Internal textures, visible in $\mathrm{CL}$, are probably formed by fluid alteration during which some of the metamict zircons have lost
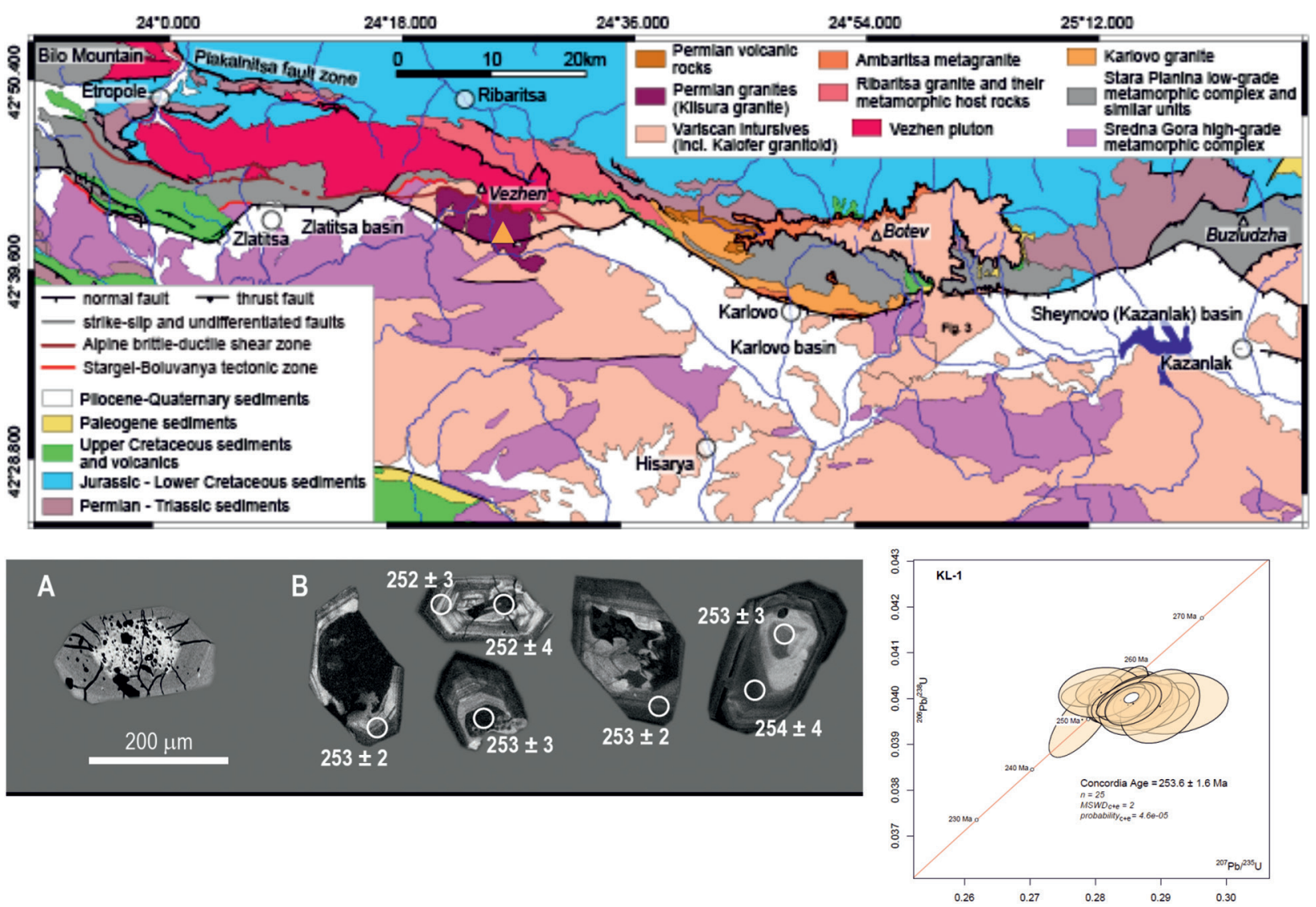

Fig. 1. Geological map of the central part the Sredna Gora and Balkan Zones compiled by Balkanska et al. (2021); the proximate sample location of KL-1 is pointed on the map with an orange triangle. Bottom, CL images of zircons and Concordia diagram. 
radiogenic $\mathrm{Pb}$. Altered zones are characterized by higher CL intensities than unaltered zones. Partially preserved growth zoning is infiltrated by recrystallization and with a local development of convolute zoning (Fig. 1). The inner parts of the grains with relics of cores are typically homogenous and the rims mostly show oscillatory/planar zonation. $\mathrm{Th} / \mathrm{U}$ ratio varies between 0.3 to 1.3 , which are typical values for magmatic zircons, the higher contents of $\mathrm{U}$ (usually in excess of $1000 \mathrm{ppm}$ ) correspond to a high degree of metamictization. A total of 25 analyses reveals core and rim concordant ages that overlap within the 2-sigma error and define a Concordia age of $253.6 \pm 1.6 \mathrm{Ma}(2 \sigma$; Fig. 1$)$.

\section{Regional context}

The age of the Klisura/Rozino granite adds a valuable information to the discussed post-Variscan but pre-Alpine magmatic activity in SE Europe. The obtained data gives further evidence of the contemporaneous intrusive and extrusive magmatism during late Permian and Early Triassic in the Sredna Gora and Balkan zones. An intermediate to acid volcanic body with a proofed late Permian age of $260.3 \pm$ 1.0 Ma (Tanatsiev et al., 2012) cut the early Paleozoic metasedimentary section in the western part of Sredna Gora zone next to the Vlado Trichkov village. Upper Permian to Lower Triassic subvolcanic bodies, dykes, and sills of ca. $251.5 \pm 1.3 \mathrm{Ma}$ (Georgiev et al., 2013) intruded the lower Paleozoic lowgrade metasedimentary sequence in Central Stara Panina Mountain in the autochthone of the Paleogene Botev Vrah thrust. In the same area is exposed the 250.1 \pm 1 Ma old (Balkanska et al., 2021) Kalofer granitoid - part of the Hisarya-Pastrovo pluton. The preliminary data about the subvolcanic and volcanic bodies, exposed next to the town of Sliven is ca. $249.27 \pm 12$ (Georgiev, 2008). All the available geochronologic data allow us to agree with the idea of two separate magmatic episodes for the Sredna Gora and Balkan zones, since the gap of at least ca. $30 \mathrm{Ma}$ between both magmatic events is a quite long time to assume a single long-lived post-Variscan magmatic activity from Late Carboniferous up to Mid Triassic. To define the actual area distribution and real volume of the late Permian to Early Triassic magmatism is still difficult task because the bodies commonly intruded Upper Carboniferous to lower Permian granitoids of the earlier episode. A good example is the Kalofer granitoid - part of the nested Hisarya-Pastrovo pluton.

The results from recent studies of granitoids and metagranitoids in the neighboring regions reveal that the products of the late Permian to Early-Mid Triassic magmatic event are widespread in Bulgaria. Two lower Triassic granitoid bodies cut the
Variscan amphibolite facies metamorphic rocks of the Ograzhden Unit of the Serbo-Macedonian Massif. In Belasitsa Mountain, a small calc-alkaline granodioritic body with volcanic-arc/continental margin or post-collisional signature known as the Skrut pluton is dated at $249 \pm 1 \mathrm{Ma}$ (Zidarov et al., 2007). West of the Sandanski town is located the Mid Triassic (243 $\pm 1 \mathrm{Ma})$ post-metamorphic Igralishte pluton (Peytcheva et al., 2009). These bodies, along with the Arnea and Kerkini granites in Greece, were considered as products related to the Neotethys opening, in spite of similar in age plutons, distinguished in the Sakar-Strandzha zone and further east in Turkey, which were connected with the Paleotethyan subduction processes (Bonev et al., 2021). However, the Neotethys rifting scenario is assumed as more plausible for the ca. 251-256 Ma Izvorovo pluton in Strandzha (Sałacińska et al., 2021).

Due to scattered data, our knowledge about the late Permian to Early Triassic magmatic activity in both the Sredna Gora and Balkan zones is still rather scanty to allow for an unambiguous geodynamic interpretation, which is a challenge for the wider peri-Tethyan realm in Europe as well. Similar ages are reported for mafic and felsic rocks, including pegmatites in the Eastern Alps (Thoni, Miller, 2000) and Western Carpathians (Putiš et al., 2019 and references therein). The data point to a late Permian-Triassic magmatic activity in the wide European realm, with still debatable tectonic setting, but most logically with a rifting-related scenario.

Acknowledgments: The financial support from the Bulgarian Academy of Sciences (Bilateral grant agreement between BAS and SAS) is gratefully acknowledged.

\section{Reference}

Antić M., I. Peytcheva, A. von Quadt, A. Kounov, B. Trivić, T. Serafimovski, G. Tasev, I. Gerdjikov, A.Wetzel 2016. PreAlpine evolution of a segment of the North-Gondwanan margin: Geochronological and geochemical evidence from the central Serbo-Macedonian Massif. - Int. J. Earth Sci., 36, 523-544; https://doi.org/10.1016/j.gr.2015.07.020.

Antonov M., S. Gerdjikov, L. Metodiev, Ch. Kiselinov, V. Sirakov, V. Valev. 2010. Explanatory Note to the Geologic Map of the Republic of Bulgaria in Scale 1:50 000. Map Sheet K-35-37-B (Pirdop). Sofia, Ministry of Environment and Water, Bulgarian Geological Survey, $99 \mathrm{p}$.

Balkanska, E., I. Gerdjikov, S. Georgiev, A. Lazarova, W. Dörr, A. Kounov. 2021. Structural and geochronological constraints on the magmatic and tectonic events in the preAlpine basement of the central parts of the Balkan foldthrust belt (Central Stara Planina Mountains, Bulgaria). Int. J. Earth Sci., 110, 1181-1211; https://doi.org/10.1007/ s00531-021-02011-1.

Bonev, N., P. Filipov, R. Raicheva, R. Moritz. 2021. Evidence of late Palaeozoic and Middle Triassic magmatism in the 
Sakar-Strandzha Zone, SE Bulgaria: Regional geodynamic implications. - Int. Geol. Rev., 1-27; https://doi.org/10.108 0/00206814.2021.1917008.

Cortesogno, L., L. Gaggero, A. Ronchi, S. Yanev. 2004. Late orogenic magmatism and sedimentation with Late Carboniferous to Early Permian basins in the Balkan terrane (Bulgaria): geodynamic implications. - Int. J. Earth Sci., 93, 500-520; https://doi.org/10.1007/s00531-004-0410-y.

Georgiev, S. 2008. Sources and Evolution of Late Cretaceous Magmatism in Eastern Srednogorie, Bulgaria: Constraints from Petrology, Isotope Geochemistry and Geochronology. $\mathrm{PhD}$ thesis, ETH Zurich, $270 \mathrm{p}$.

Georgiev S., E. Balkanska, I. Gerdjikov. 2013. Evidence for Permian-Triassic acid magmatism in the Central Balkanides. - Proc. Nat. Conf. Bulg. Geol. Soc., Geosciences 2013, 23-24.

Georgiev S., I. Gerdjikov, I. Peytcheva, P. Makaveev. 2020. Time frame of the Carboniferous tectonic and magmatic activity in the area of Vezhen pluton, Bulgaria. - Rev. Bulg. Geol. Soc., 81, 3, 72-74.

Kamenov, B., A. von Quadt, I. Peytcheva. 2002. New insight into petrology, geochemistry and dating of the Vejen pluton, Bulgaria. - Geochem., Mineral. and Petrol., 39, 3-25.

Kuykin, S., L. Milanov, L. Katseva. 1974. Sredna gora granitoids from the southern slopes of the Vezhen massif and the northern parts of Sredna Gora proper. - Rev. Bulg. Geol. Soc., 35, 3, 277-290 (in Bulgarian with English abstract).

Okay, A., G. Topuz. 2017. Variscan orogeny in the Black Sea region. - Int. J. Earth Sci., 106, 2, 569-592; https://doi. org/10.1007/s00531-016-1395-z.
Peytcheva, I., A. von Quadt, M. Tarassov, N. Zidarov, E. Tarassova, V. Andreichev. 2009. Timing of Igralishte pluton in Ograzhden Mountain, SW Bulgaria: implications for the tectono-magmatic evolution of the region. - Geologica Balc., 38, 5-14.

Putiš, M., F. Koller, X.-H. Li, Q.-L. Li, A. Larionov, P. Siman, M. Ondrejka, P. Uher, Z. Németh, P. Ružička, O. Nemec. 2019. Geochronology of Permian-Triassic tectono-magmatic events from the Inner Western Carpathian and Austroalpine units. - Proc. Geol. Carpath. 70 Conf., 119-122.

Sałacińska, A., I. Gerdjikov, A. Gumsley, K. Szopa, D. Chew, A. Gawęda, I. Kocjan. 2021. Two stages of Late Carboniferous to Triassic magmatism in the Strandja Zone of Bulgaria and Turkey. - Geol. Mag.; https://doi.org/10.1017/ S0016756821000650.

Tanatsiev, S., M. Ichev, S. Pristavova. 2012. U-Pb zircon dating of the acid volcanic rocks from the Sofia Stara Planina (Balkan) Mountains, West Bulgaria. - Proc. Nat. Confer. Bulg. Geol. Soc., Geosciences 2012, 69-70.

Thöni, M., C. Miller. 2000. Permo-Triassic pegmatites in the eo-Alpine eclogite-facies Koralpe complex, Austria: age and magma source constraints from mineral chemical, Rb$\mathrm{Sr}$ and $\mathrm{Sm}-\mathrm{Nd}$ isotope data. - Schweiz. Mineral. Petrogr. Mitt., 80, 2, 169-186.

Zidarov, N., E. Tarassova, I. Peytcheva, A. von Quadt, V. Andreichev, R. Titorenkova 2007. Petrology, geochemistry and age dating of Skrut granitoids - new evidence for Lower Triassic magmatism in Belassitsa Mountain (SW Bulgaria). - Geologica Balc., 36, 1-2, 17-29. 